Masthead Logo

digitalcommons.nyls.edu

2018

Procedure Deficits in Protection for Immigrant Children in the United States

Lenni Benson

Claire R. Thomas

Follow this and additional works at: https://digitalcommons.nyls.edu/fac_articles_chapters 


\section{Procedure deficits in protection for immigrant children in the United States}

\section{Lenni B. Benson and Claire R. Thomas}

\section{INTRODUCTION: PROCEDURE MATTERS}

In theory, United States (US) immigration statutes offer many forms of protection and integration for foreign national youth. ' In practice, however, the ability of young people to access relevant special visa categories is frustrated by process barricrs and the lack of adcquate information and skilled counsel. ${ }^{2}$

Under US law, migrant children may scek protection as refugecs; they may qualify for permanent residence if they have been abandoned, abused or neglected by a parent; they may be protected if victims of crimes or trafficking. Other contributors have defined and explained the substantive requirements for each form of protection. ${ }^{3}$ In this chapter, we explore whether US domestic legal systems protect children's procedural rights. We note at the outset that the US Constitution has been applied

1 Child migration in the United States has a long history. Early laws excluded only those young people judged inadmissible on grounds of diseasc, lack of mental capacity or likelihood that they would become dependent on public welfare support. Similar exclusions applied for adult applicants for admission. In 1907, Congress adopted the Immigration Act 1907 to prohibit the admission of any child under 16 traveling without one or both parents. Even then, exceptions were made for some unaccompanied children sent to the US to escape war or persecution. See 38 Statutes-at-Large 898 (20 February 1907), s. 2.

2 In reality, most unrepresented children are unable to identify any form of relief. Based on regular Freedom of Information Act data, 'TRAC' academics at Syracuse University publish information about the juvenile cases in the Immigration Court. The data shows that between 2005 and the end of 2016, only $4 \%$ of unrepresented children could secure any relief in Immigration Court, see http://trac.syr.edu/phptools/immigration/juvenile/.

3 For a discussion of the options available to children, sce David Thronson, Chapter 13; Kate Bones and Timnah Baker, Chapter 14. 
consistently to protect both citizen and foreign-born children in regards to fundamental rights such as education, safety and criminal punishment. ${ }^{4}$

Between October 2010 and October 2016, the US government initiated 177,561 removal or deportation cases against children. ${ }^{5}$ of these, 41 percent or 73,013 cases remained pending in mid-2017. This suggests that children are given time and process in removal proceedings. In this chapter we examine some of the reasons why 'due process' does indeed require time, as we explore measures that would greatly reduce the procedural protections that have been available.

The presidential election in 2016 led the Department of Homeland Security (DHS), which controls most aspects of immigration enforcement, ${ }^{6}$ to rapidly shift its policies and operations. Many of the children who were able to apply for protection at the US Southern border with Mexico may find that new 'fast track', truncated procedures will literally close the door. ${ }^{7}$ Others already present within US territory may find an increased focus on apprehension, detention and removal proceedings. As fear of enforcement grows, many have become concerned about the special vulnerability of children, with news reports of a decrease in school attendance in many immigrant communities. ${ }^{8}$

4 In Plyler v. Doe, 457 US 202 (1982), the US Supreme Court recognized that all children have a right to free public education regardless of the immigration status of the child. Children are not criminally punished for immigration violations and immigration proceedings are characterized as 'civil enforcement'.

5 Calculations based on reviewing TRAC data between 2010 and end of 2016, see http://trac.syr.edu/phptools/immigration/juvenile/, calculated on 2 April 2017; $19 \%$ of the cases were completed with an in absentia removal order because the child failed to appear. In the vast majority of these cases the child had no attorney.

6 The DHS is a cabinet level agency with many divisions, including Customs and Border Protection (CBP), US Citizenship and Immigration Service (USCIS) and its Asylum Directorate, and the Immigration and Customs Enforcement (ICE). The Immigration Court, the Executive Office for Immigration Review (EOIR), is an administrative component within the Department of Justice.

7 See Secretary John Kelly, Department of Homeland Security, Implementing the President's Border Security and Immigration Enforcement Improvements Policies (Memorandum, 17 February 2017), announcing a change in treatment of children and authorizing the use of expedited removal at the border and within the interior of the US ('Kelly Memo'). In 2017 the United States was already returning Mexican and Canadian children to their respective countries under special treaty agreements. Few are admitted to the US unless the child is able to articulate that he or she is a victim of severe trafficking. See discussion below.

8 See, e.g., V. Yee, 'Immigrants hide, fearing capture on any corner', New York Times, 22 February 2017; M. Anderson, 'How Fear of Deportation Harm Kids' Education', Atlantic Monthly, 26 January 2017; National Public Radio, 


\section{LOCATION DEFINES THE SCOPE OF PROCESS}

People seeking admission to the US territory have very few statutory or constitutional rights. ${ }^{9}$ Traditionally, people who have entered, with or without authorization, enjoy greater procedural and substantive protections. Until the passage of legislation in 2008 , children had no greater statutory protections than any other non-citizen seeking admission to the United States. As is discussed below, if border officials agree that a child merits the designation of unaccompanied child, the procedural protections are dramatically increased.

\subsection{At the Border}

Since 2008, children have had significant procedural protections under the William Wilberforce Trafficking Victims Protection Reauthorization Act 2008 (TVPRA). ${ }^{10}$ This statute exempts unaccompanied children from 'expedited removal' procedures. ${ }^{11}$ Unaccompanied children hoping to enter the United States present themselves at the Southern border with Mexico at official ports of entry or are apprehended by Customs and Border Protection (CBP) officials within the US. ${ }^{12}$ CBP officials intercept the children once they enter the US territory and take them into custody. ${ }^{13}$

'Attendance drops at Maryland High School as deportation fears rise', 16 January 2017.

9 Since the end of the twentieth century, US case law has given Congress plenary authority to define the scope of procedural due process for people seeking admission to the United States: Chae Chan Ping v. United States, 140 US 581 (1889); United States, ex rel. Knauff v. Shaughnessy, 338 US 537 (1950). Only returning lawful permanent residents have been able to secure a greater measure of procedural protections when returning from a brief sojourn abroad: Landon v. Plascencia, 459 US 21 (1982).

10 See PL 110-457 (23 December 2008) (TVPRA). While Congress created some procedural protections in this statute, many of the restraints on prolonged detention of children reflect class action litigation that has endured for over 20 years. See Flores v. Reno settlement, updated to reflect the current US Attorney General as Flores v. Lynch, discussed below n. 26.

11 Compare Australia's expedited processing procedures, as discussed by Savitri Taylor in Chapter 18.

${ }_{12}$ The most common entries occur near Brownsville, Texas where children cross the Rio Grande River between Mexico and the United States.

13 In 1993, the US Supreme Court ruled that the US Coast Guard, now a division of DHS, may refuse to process the asylum applications for people interdicted at sea. See Sale v. Haitian Centers Council, 509 US 155 (1993). By 2017, very few children were being found in US or international waters. DHS policy announced in February 2017 may encourage irregular maritime migration as children's claims 
As a result, hundreds of thousands of children have been initially detained. The majority have been released to close relatives. As most children are arriving from Central America, the children ultimately face removal proceedings in the States with large populations of Central American migrants. The top six States, representing more than 60 percent of the released children, have consistently included: Texas, California, Florida, New York, Maryland and Virginia. ${ }^{14}$

Congress has limited these TVPRA procedural protections for children from Mexico and Canada: children from these two border nations may be immediately returned, ${ }^{15}$ unless they can articulate a clear fear of trafficking or immediate harm. ${ }^{16}$ Legislation pending in Congress in May 2017 would amend the TVPRA to require processing children's cases at border facilities. ${ }^{17}$

Children who manage to cross into the United States with family members may receive fewer procedural protections. Technically, all people apprehended near the international land border without genuine/valid documents are potentially subject to 'expedited removal'. The effect of such an order is to authorize the immediate expulsion of the individual and bars entry for a minimum of five years. There is no right to counsel in these proceedings. ${ }^{18}$

DHS did not use the expedited removal procedure on unaccompanied

are denied or curtailed at international land borders. DHS officials who encounter children at sea do have the option to bring them to the mainland, placing them into removal proceedings.

14 For State release statistics see www.acf.hhs.gov/orr/programs/ucs/stateby-state-uc-placed-sponsors. In 2016, these States represented 31,796 children out of a total of 52,147 referred from the border to DHHS care.

15 Between 2013 and fall 2016, 138,611 Central American youth were apprehended at the US Southern border. See statistics generated by CBP at www.cbp. gov/newsroom/stats/southwest-border-unaccompanied-children/fy-2016. In this same time period, an additional 36,400 Mexican youth were apprehended by US border authorities. Almost all were summarily returned to Mexico. There is no statutory right to counsel during the border inspection. No child advocate organization advises children at the early inspection stages.

16 See agreements between the US DHS and Mexico. See generally B. Cavendish and M. Cortaza, Children at the Border (Appleseed, 2011), available at http:// appleseednetwork.org/wp-content/uploads/2012/05/Children-At-The-Border1.pdf.

17 See, e.g., Protection of Children Act 2017, HR 495.

18 The case law concerns adults as the DHS did not use expedited removal on unaccompanied children. See generally Castro v. United States Department of Homeland Security, 835 F.3d 422 (3d Cir. 2016) (finding no habeas jurisdiction to raise constitutional claims of adults and children subjected to expedited removal and objecting to lack of counsel), en banc review denied, cert. denied US Sup. Ct (17 April 2017), and United States v. Peralta-Sanchez, 847 F.3d 1124 (9th Cir. 
minor children until early 2017, when then DHS Secretary Kelly changed the policy for some of the apprehended children. Again, the entire deportation decision process is made by DHS officials: children only reach an asylum officer or judge if able to articulate a credible fear of persecution. ${ }^{19}$ Secretary Kelly stated that children with a parent residing in the United States would no longer be treated as 'unaccompanied' and deserving of the additional process protections and asserted that 60 percent of the unaccompanied children were released to a parent residing without status in the US. Kelly directed DHS to prosecute if the parent had directly or indirectly facilitated the child's unlawful entry into the US. A likely response to this policy is that future children arriving alone will be reluctant to reveal the location of a parent within the US. Thus, more children may remain in Department of Health and Human Services (DHHS) custody until suitable other adults can be found to serve as host families. ${ }^{20}$ In addition, as of 2018, DHS has been separating accompanied children from their parents and detaining each separately, adding even more children to the custody of DHHS. ${ }^{21}$

If the government implements a policy of subjecting children to expedited removal, few children are likely to move beyond the initial border assessment. For the adult population, 44 percent of all forced removals are made using these expedited procedures. In theory, if a child is able to articulate a credible fear of persecution or can demonstrate he or she is a victim of trafficking, the child would be entitled to greater procedural protections and an opportunity for an interview with an asylum officer and potentially review before an immigration judge. However, there is no statutory right to counsel at the border assessment. Without counsel, it is our experience that few children are able to explain the context of their fear of return. If the expedited removal of youth does become the norm, the government of Mexico may face a growing population of displaced and unaccompanied youth. ${ }^{22}$

2017) (rejecting collateral attack on an adult's expedited removal order and finding no right to counsel).

19 Kelly Memo, above n. 7.

20 The Flores settlement does require DHHS to consider release to other relatives and to third parties who are willing to undertake the duties of a 'sponsor'. One of the primary duties of the sponsor is to ensure the child appears at his or her removal hearing.

${ }^{21}$ See C. Dickerson, 'Hundreds of Immigrant Children Have Been Taken from Parents at U.S. Border', New York Times, 20 April 2018. The agency is then classifying the children as 'unaccompanied' and initiating removal proceedings separately from the parents.

22 For a general report on the interdiction of Central American youth in Mexico, see Human Rights Watch, Report: Closed Doors: Mexico's Failure to Protect 


\subsection{Inside the Territory}

A child born on US territory usually becomes a citizen at birth. ${ }^{23} \mathrm{~A}$ significant number of people enter and overstay an authorized period of visit; in early 2017, the United States had an estimated 11 million undocumented residents. Many are children who have lived most of their lives within the territory but have no clear path to regularization of status. Unless they can navigate the substantive laws or qualify for special protections, these youth are almost as vulnerable to removal as the adult unauthorized population.

Migrant children inside the United States who can prove 'lawful inspection' and admission may seek to extend or change their temporary status. US statutes usually preclude extensions or adjustment to permanent status if a temporary status has expired or if the terms of the original admission were violated. One of the unique protections for children who enter with inspection is that they formally do not begin to acquire unlawful presence in the US until after they turn 18 . While they are not formally in status, they don't begin to face the 10-year bar to regularization of status adults face. ${ }^{24}$ In theory, such children could regularize their status without the severe penalties such as a 10-year bar to status that are imposed on adults. Nevertheless, the majority of these children grow up to become adults trapped in the unauthorized population because, for most people, there is no statutory path to regularization of status. For over 10 years, the US Congress has refused to pass legislation that would

Central American Refugee and Migrant Children (31 March 2017), available at www. hrw.org/report/2016/03/31/closed-doors/mexicos-failure-protect-central-americanrefugee-and-migrant-children. The Mexican government has reported that $38 \%$ of the children it apprehends are seeking to travel to the United States to join a parent. See Comisión Nacional de Los Derechos Humanos, México, Situación General, available at www.ohchr.org/Documents/HRBodies/HRCouncil/AdvisoryCom/ Migrant/MexicoCNDH.pdf. This is smaller than the $60 \%$ reported by DHS Secretary Kelly (above n. 7).

${ }_{23}$ The United States began to codify citizenship at the end of the Civil War. Realizing the need to incorporate former slaves born in US territory, the Congress and the States ratified an amendment to the Constitution to guarantee US citizenship to all born in US territory. Thereafter, further regulations were created to allow children born abroad to at least one citizen parent to also acquire citizenship at birth. See INA, ss. 301(g), 309; 8 USC ss. 1401(g), 1409. People claiming citizenship at the border bear the burden of proof.

24 INA, s. 212(a)(9)(b); 8 USC s. $1182(\mathrm{a})(9)(\mathrm{b})$ punishes an illegal entrant or person who overstayed for more than 365 days with a 10 -year bar if they depart and seek reentry to the United States. Children do not become subject to this penalty until they turn 18 . 
give permanent residence to individuals brought to the US as children. By 2017 , approximately 650,000 youth had been able to secure a form of stay of removal and temporary work authorization under President Obama's Deferred Action for Childhood Arrivals ('DACA') Program. The Trump Administration terminated the DACA Program in an announcement on 5 September 2017, suggesting that only Congress can protect these children raised within the US. As of May 2018, court orders challenging the termination of DACA are still pending. USCIS is accepting DACA renewals, but no new applications for DACA may be made. ${ }^{25}$

The DHS can arrest, detain and deport any individual who fails to maintain status in the United States or who is apprehended within the interior but cannot establish lawful admission. For many years, children were rarely placed in removal proceedings except as part of a parent's deportation case. Children's remedies or opportunities to remain were almost exclusively derivative of the rights of the parent to remain. ${ }^{26}$

As the DHS began to apprehend more children at the border, the agency policy shifted to also initiate removal proceedings against a greater number of unaccompanied children found within the interior. The DHS had focused previously on children who engaged in acts of juvenile delinquency or who were found within close proximity to the border. It is unclear whether the new administration will broaden interior enforcement beyond these categories of children.

\section{DETENTION AND INITIATION OF REMOVAL PROCEEDINGS}

After the initial apprehension and processing by DHS, the federal government transfers migrant children from border control authorities to the care and custody of the DHHS. ${ }^{27}$ For more than 20 years, the Flores class

25 See USCIS website on DACA, at https://www.uscis.gov/humanitarian/ deferred-action-childhood-arrivals-response-january-2018-preliminary-injunction.

26. There is no universal procedural mechanism for providing accompanied children with an independent advocate or 'guardian ad litem' to ensure that the best interests of the child are preserved. If the CBP believes a child is being trafficked, the agency may seek intervention of special protection officers who might seek to separate the parent and child. We found no statistics reporting this intervention. Interviews with DHS personnel suggested this rarely occurs.

27 See Chapters 18 through 21 for a discussion of the detention of children. For a detailed article discussing the rights of child migrants held in detention and similarly arguing for a right to appointed legal counsel, see E. Frankel, 'Detention and Deportation with Inadequate Due Process: The Devastating Consequences 
action litigation limited the government's ability to detain children. ${ }^{28}$ The Flores decision and resulting settlement requires the federal government to release children held in civil detention as soon as possible, and not solely to the child's natural parent. ${ }^{29}$ In 2016 , a federal court confirmed that these limits apply to all children, whether apprehended alone or with a parent. ${ }^{30}$ Children who have a parent or parents in the United States traditionally have been released quickly from federal detention. ${ }^{31}$

While there is no right to appointed defense counsel, Congress has authorized a 'child advocate' program, which has been primarily reserved for children who remain in detention. ${ }^{32}$ The child advocate may be a trained attorney who tries to assist the child by serving as an independent evaluator of the child's best interests. She or he makes recommendations about release from federal custody or assesses whether a child can be safely repatriated to his or her country of origin. The role of the advocate is limited and does not include the direct representation of the child before the court, nor assistance in the preparation of applications for relief from removal. Unfortunately, the assessment of a child's best interests is not

of Juvenile Adjudications for Immigrant Youth' (2011) 3(63) Duke Forum on Law and Social Change, available at http://scholarship.law.duke.edu/dflsc/vol3/iss1/4. The DHHS reported that the detention program cost over US\$948 million in fiscal year 2016, see www.acf.hhs.gov/orr/unaccompanied-children-frequently-askedquestions. The DHS spends over US\$2 billion annually on the detention of adult non-citizens.

28 Flores Settlement Agreement, available at http://centerforhumanrights. org/PDFs/05-19-16_Flores_Press_Statement.pdf. Some of the agreement's terms have been codified at 8 CFR ss. 236.3, 1236.3. See also Reno v. Flores, 507 US 292 (1993) (related case discussing due process rights of children).

${ }_{29}$ See Cavendish and Cortazar, Children at the Border, above n. 16, at 32 for a discussion of related litigation on child detention and conditions.

30 Flores v. Reno, renamed Flores v. Lynch, 828 F.3d 898 (9th Cir. 2016) (interpreting the settlement agreement and finding it applics to all minors in DHS custody but does not compel release of parents with children).

31 The federal government has reported that $85 \%$ of the children are released within 21 days. For fiscal year 2016, the agency reported an average length of detention of 34 days, see www.acf.hhs.gov/orr/about/ucs/facts-and-data.

32 See discussion of the right to counsel below. Congress authorized a pilot Chuld Advocates program, administered by the Young Center based at the University of Chicago Law School, see www.theyoungcenter.org. See J. Nagda and M. Woltjen, Best Interests of the Child Standard: Bringing Common Sense to Immigration Decisions (First Focus, 2015); and Frankel, 'Detention and Deportation with Inadequate Due Process', above n. 25, at 63. The Young Center provides advocacy services for children in several US regions. Again, these child advocates do not serve as 'attorneys' for the child in immigration proceedings. In many instances, the unaccompanied child lacks any legal counsel. 
universally incorporated into the adjudications before either the asylum office or the Immigration Court.

\section{PROCESS IN REMOVAL PROCEEDINGS}

Children apprehended at the border bear the burden of proving eligibility to enter and to remain within the United States. In contrast, when an individual is apprehended in the interior, the DHS must establish by clear and convincing evidence that the person is an alien and is subject to a statutory ground of removal. ${ }^{33}$ At the removal hearing, the immigration judge, a form of administrative hearing officer, may entertain applications for relief from removal. ${ }^{34}$ All people in removal proceedings have a right to counsel but 'not at expense to the government'. ${ }^{35}$

If a child is able to articulate a request for protection before the court, the resulting procedure is largely dictated by the type of protection the child is seeking. As of 2016, children had greater process protections than adults in removal, with dockets segregated from adult cases. If a child is seeking asylum, the adjudication is taken out of the adversarial process and the child is given an informal hearing with a trained refugee/asylum officer. The asylum procedures are the most protective of a child's needs but almost all applications are made outside the cauldron of the court itself. ${ }^{36}$

Children may seek protection under the Refugee Convention and several other US statutory protections designed for victims of crime or trafficking. Congress has also authorized a form of protection for children who have been subject to a State court family law determination of abuse, neglect or abandonment. In most instances, the first adjudication of eligibility for these forms of protection are made in fora outside the Immigration Court.

Between 2005 and the end of January 2017, the Immigration Court

33 INA, s. 240, 8 USC s. 1229a.

34 The Immigration Court is formally called the Executive Office for Immigration Review (EOIR) and is an agency within the US Department of Justice (DOJ). It is not an independent court nor a formal part of the judiciary. See www.usdoj.gov/eoir. Immigration Judges are attorneys appointed by the Attorney General. The prosecuting agency within the EOIR is the Immigration and Customs Enforcement (ICE) division of the DHS.

35 INA, s. 292, 8 USC s. 1362. The need for and right to counsel is explored below.

36 The $\mathrm{T}$ status, the $\mathrm{U}$ status and the Special Immigrant Juvenile status forms of protection each involve different procedures outside the Immigration Court. See discussion below (text at n. 47). 
adjudicated over 216,000 juvenile cases. ${ }^{37}$ The vast majority involved children apprehended at the US border but released into the interior. ${ }^{38}$

\subsection{Unaccompanied Children}

DHS places all unaccompanied children in the removal system, regardless of whether the child is detained or released to a sponsoring adult. Fearful that delays in adjudication were encouraging youth to seek to enter the United States, the DHS issued directives in 2014 that listed recent border arrivals, including unaccompanied children, as its top enforcement (prosecutorial) priorities. ${ }^{39}$ The Executive Office for Immigration Review (EOIR) also prioritized unaccompanied children's removal cases, scheduling the first hearing within 21 days of the DHS lodging the Notice to Appear (the charging document).

In early 2017, President Trump and DHS Secretary Kelly revoked these priorities memoranda and expanded the agency priorities to all who have engaged in any criminal conduct. ${ }^{40}$ The Immigration Court priority docket characterizations were also formally rescinded by the Office of the Chief Immigration Judge on 31 January 2017. Only children remaining in DHHS custody will remain priority cases. ${ }^{41}$ These policies are likely to produce slower adjudications for children's claims within the Immigration Court.

For the most part, the Immigration Court serves as an expensive, cumbersome monitor of the case while the child must seek substantive protection in other fora. Some cases go to State family courts and then to the United States Citizenship and Immigration Service (USCIS) benefits section. ${ }^{42}$ Others go to the USCIS asylum office for primary jurisdiction. Thus, the

37 See Juvenile in Immigration Court data available at www.trac.syr.edu/ phptools/immigration/juvenile.

38 In contrast, the government's burden is reduced to submitting proof of proper service of the allegations of alienage and charges of inadmissibility.

39 Secretary J. Johnson, Department of Homeland Security, Memorandum (25 November 2014), rescinded by Kelly Memo, above n. 7. For many years, ICE was usually willing to close removal or deportation proceedings and allow the migrant child to live temporarily within the United States through a grant of prosecutorial discretion. February 2017 guidance suggests that future prosecution decisions are to be made on a case by case basis: Kelly Memo, above n. 7 . Prosecutorial discretion closing the removal case does not give the child formal status nor any affirmation or authorization to work or travel; the child remains in the 'undocumented' population but without threat of immediate removal.

40 See Kelly Memo, above n. 7.

41 Chief Immigration Judge Mary Beth Keller, Case Processing Priorities (31 January 2017, on file with author).

42 See above n. 6. 
process a child experiences in the removal hearing is highly dependent on having counsel and the specific form of protection. These varied procedures are outlined in more detail below. Once a form of substantive protection is secured, the child can seek a termination of the removal proceedings.

Phrased differently, almost all children's cases are put into adversarial removal proceedings where a child risks a deportation order, yet the opportunities for protection are largely adjudicated elsewhere. Unfortunately, without competent legal counsel, the EOIR procedure is inadequate to both direct the child toward relief or to help the child obtain even minimal substantive protection. Only 12 percent of children who appear in removal proceedings without counsel are granted relief or any discretionary right to remain. In contrast, 86 percent of children who are represented are usually able to obtain an end of the removal and a form of authorization to remain such as asylum or other relief. ${ }^{43}$

Further, in many cases, no form of relief can be found and the government may agree to an administrative closure, allowing the young person to remain. Again, this is much more likely to happen if the child is represented. Between 2014 and 2017, the official DHS policy was to oppose prosecutorial discretion for recent border crossers, including children, who entered after January $2014 .{ }^{44}$ The Immigration Judge cannot force the government to accept administrative closure or termination. In most cases, the parties agree to this conclusion. Between 2005 and January 2017 , approximately 30,000 children of over 215,000 cases had received a form of administrative closure or prosecutorial discretion. ${ }^{45}$

Even with the high rate of closure, the official policy between 2014 and 2016 was to discourage prosecutorial discretion for newly arriving children. In 2017, the Trump Administration issued a policy memorandum that both appeared to broaden the power of government prosecutors to grant administrative closure, while at the same time instructing DHS to investigate

43 Data is based on analysis of rates of representation and outcomes reported by Immigration Judges to staff at TRAC at the Syracuse University, see http:// trac.syr.edu/phptools/immigration/juvenile/. One possible explanation may be that counsel select cases of children who have a potential for relief. Until there is a release of data for the small pilot program attempting to provide nearly universal representation in a handful of immigration courts, it is not possible to determine if the provision of counsel alone is the predominate cause for the difference in outcomes. Moreover, many deportation orders for children are issued after the child fails to attend the administrative hearing, as in absentia orders of removal. The in absentia rate for completed cases $2010-2016$ was $19 \%$. Only $5.8 \%$ of those subjected to in absentia orders were represented.

44 Johnson, Memorandum, above n. 39.

45 See TRAC data, above n. 5 . 
whether unaccompanied children can be repatriated to their country of origin. ${ }^{46}$ However, on 17 May 2018 the Attorney General of the US, Jeff Sessions, issued a decision ending the ability of Immigration Judges to grant administrative closures if either party objected. ${ }^{47} \mathrm{At}$ time of writing it was too early to assess how aggressively the new administration will pursue removal of children at the border. What is clear is that Immigration Judges have fewer tools to temporarily close removal cases, even if the child has an application for relief pending before another agency.

\subsection{Accompanied Children or Other Juveniles}

A child apprehended with a parent and placed into removal proceedings may sometimes qualify for protection when his or her parents do not. If the government and parents consent, the removal cases may be separated. ${ }^{48}$ For example, a child may meet the standards for special immigrant juvenile status, a form of permanent residence and successfully obtain legal status and terminate the proceedings. However, his or her parent would have no parallel defence to removal. For most of the statutory forms of protection, a child cannot sponsor his or her parent directly for derivative protection. In these cases, the parent may try to seek prosecutorial discretion to be allowed to remain in the United States until the child reaches the age of majority. There is no statutory or constitutional right to remain in the US because your child is a citizen or has been granted protective status. Only the special visa categories for victims of crimes or of trafficking expressly allow a parent to receive derivative protection based on a child's application. ${ }^{49}$

\section{CHILDREN'S ASYLUM CLAIMS: PROCESS ALONE CANNOT PROTECT A CHILD}

\subsection{Asylum Office Process}

People in removal proceedings are not usually able to process their application before the non-adversarial USCIS Asylum Office. In contrast,

See Kelly Memo, above n. 7.

Matter of Castro-Tum, 27 I \& N Dec. 271 (17 May 2018).

A child who is not designated an 'unaccompanied child' is still entitled to child-appropriate procedures under the Immigration Court procedures. See Court Memorandum, OPPM 07-01, discussed below.

49 See U or T status and regulations found in 8 CFR 214.2. 
Congress expressly granted unaccompanied children the right to have an application assessed by the Asylum Office even if the child has been placed into removal proceedings. ${ }^{50}$ Non-citizen children appear before an Asylum Officer in two contexts: as accompanied minors who appear as derivatives on their parents' asylum applications ${ }^{51}$ or as unaccompanied minors who apply for asylum independently. ${ }^{52}$

Normally, an individual has only one year to seek asylum unless he or she can establish extraordinary circumstances to justify a late filing. ${ }^{53}$ Under current interpretation, if a child was classified at apprehension as an unaccompanied child, he or she is expressly exempt from this deadline. ${ }^{54}$

Whether an asylum claim is made by a child or an adult, the applicant must show that:

(1) she meets the statutory definition of a 'refugee', as found in Immigration and Nationality Act (INA), section 101(a)(42)(A);

(2) that she is not subject to any statutory bars from asylum; and

(3) that she merits a grant of asylum in the adjudicator's discretion. A child meeting these three criteria may be granted asylum or refugee status under INA, section 208.

While a child must prove the same elements as an adult to be eligible for asylum, a child's asylum claim often differs from an adult's case. One

so TVPRA, above. The USCIS Asylum Office officially created a policy of primary jurisdiction in 2013. See also USCIS, Affirmative Asylum Procedures Manual (USCIS, May 2016), s. III.B, 35, available at www.uscis.gov/humanitarian/ refugees-asylum/asylum/affirmative-asylum-process.

51 A child can qualify for derivative asylum benefits if he or she is under 21 and unmarried. If the parent secured asylum inside the United States but the child or spouse were abroad, the parent may sponsor the family members for derivative refugee benefits and bring them to the United States.

52 The Kelly Memo, above n. 7, may change the Asylum Office initial jurisdiction for defensive applications filed in immigration court. It is unclear as of this writing. See also Chief Immigration Judge and Asylum Office, Memorandum on Jurisdiction (2 April 2013). May be superseded by Kelly Memo, above n. 7.

5.3 See INA, s. 208(a)(2)(d); 8 USC s. 1158(a)(2)(d). There are exemptions to this deadline such as when an individual can show he or she was suffering a severe mental or emotional impairment.

\$4 Sce INA, s 208(a)(2)(e); 8 USC s .1158(a)(2)(e) exempting 'unaccompanied alien children'. The Kelly Memo, above n. 7, suggests reclassification if a child is ultimately reunited with a parent, which implies that children may find asylum claims time-barred in future if they cannot meet the deadline nor utilize an alternative exception. 
example of this difference lies in the experience of persecution. For an adult asylum applicant, persecution often entails the applicant directly experiencing mistreatment. However, for a child, merely witnessing violence could be construed as persecution. ${ }^{55}$ Further, as scholars note, 'a migrating child exposed to gross violations of social or economic rights may require protection from the United States in circumstances where an adult who endured the same experience might not, because for the child this may amount to persecution'. ${ }^{56}$

The Asylum Office has extensive guidelines that instruct the adjudicators about child protective interviewing policies such as allowing times for breaks or the ability for the child to bring an adult to the interview in a supportive role. ${ }^{57}$ One of the most important protections in the guidelines required headquarters review of all decisions where a child was going to be refused asylum. Due to the sharp increase in the number of claims, the Asylum Office instituted a random selection of cases for review. ${ }^{58}$ Shortly after the change the number of refused cases began to grow. ${ }^{59}$ The cases refused at this Office are returned or referred to the Immigration Court. In January 2018, the Asylum Office adjusted its workload priorities for scheduling cases. Previously, asylum cases for unaccompanied children were prioritized, but following this change, unaccompanied children no longer have a priority in case scheduling. Instead, the Asylum Office will schedule the most recently filed cases first. ${ }^{60}$

\subsection{Referred Back to the Immigration Court}

When the Immigration Court receives a referred asylum claim, the judge must apply a de novo review of the application. The Immigration Judge will allow supplemental filings and new evidence and testimony may be

55 For further discussion about the differences between how a child and an adult view persecution, see J. Bhabha, 'Not a Sack of Potatoes' (2006) 15 Boston University Public Interest Law Journal 197, at 210.

56 Ihid. 210. For more, see Kate Bones and Timnah Baker, Chapter 14.

57 Guidelines available at www.uscis.gov/sites/default/files/USCIS/Laws\%20 and $\% 20 \mathrm{Regulations/Memoranda/Ancient} \% 20 \mathrm{History} / \mathrm{Childrens} \mathrm{Guidelines}$ 121098.pdf.

58 The change was identified in a FOIA request and reported by a private law firm that represented hundreds of children seeking asylum, see https:/amjolaw. $\mathrm{com} / 2016 / 11 / 12 /$ throwing-children-asylum-applicants-to-the-wolves/.

59 Ibid., reporting a drop from $60 \%$ to $41 \%$ in 2015 and $38.2 \%$ in 2016 .

6) See Affirmative Asylum Interview Scheduling, at https://www.uscis.gov/ humanitarian/refugees-asylum/asylum/affirmative-asylum-interview-scheduling. 
considered in the administrative merits hearing. These hearings are conducted as adversarial trials and the government is represented by a DHS attorney. The burden is on the child to establish his or her eligibility for protection. While formal rules of evidence are not applied as they would be in State and federal courts, the proceedings are governed by the procedural rules of the Immigration Court and evidence is tested for probative value and authenticity. ${ }^{61}$

The statutes do not provide additional procedural protections for children's asylum hearings. However, the Immigration Court has introduced special procedural guidelines that instruct the judge to be aware of the particular vulnerability of juveniles. ${ }^{62}$ The procedures expressly explain that the 'best interests of the child' standard 'does not negate the statute or the regulatory delegation of the Attorney General's authority, and cannot provide a basis for providing relief not sanctioned by law' ${ }^{63}$ These procedures identify several areas where a judge may deviate from usual procedure such as appearing before the child without a judicial robe or allowing time for the interpreter to become familiar with the child. The procedures also suggest that judges should recognize 'for emotional and physical reasons, that children may require more frequent breaks than adults'. ${ }^{64}$

The court procedures also suggest that the Immigration Judge attempt to adapt the questioning and structure of the hearing to avoid making it unduly adversarial. It includes examples that illustrate how a judge and/or the attorneys representing the government or the child should use simple questions, avoid leading questions, and understand that children may have difficulty testifying to difficult situations. ${ }^{65}$

While the child is entitled to request a copy of the asylum adjudicator's notes made during the asylum interview, the child does not receive the full written assessment evaluating the application. The DHS prosecutor does have access to the entire application and may use material in the file as a basis for cross-examination or impeachment in the subsequent merits hearing before the Immigration Judge.

If a child's claim for asylum is granted, the removal proceeding is

61 See generally, INA, s. 240, 8 USC s. 1229a. The regulations governing asylum adjudication provide more guidance, 8 CFR $1208 \mathrm{ff}$.

62 EOIR, Operating Policies and Procedures Memorandum 07-01 (22 May 2007) (OPPM 07-01). This OPPM replaced a similar prior set of guidelines issued in 2004.

${ }^{63}$ Ibid. s. III.B, at 4.

${ }_{64}$ Ibid. s. V6, at 7.

65 See especially ibid. Appendix A for examples of child appropriate questions. 
terminated. One year later, a child may seek a formal adjustment of status to full permanent resident status. With this status, once the young person has resided in the United States for four more years and has turned 18, he or she can seek to naturalize as a US citizen. ${ }^{66}$

If the court does not approve the child's application for protection, the child may appeal the decision to the Board of Immigration Appeals and ultimately to the federal Circuit Court of Appeals. ${ }^{67}$ Current statistics do not code cases based on the age of the person in the proceedings and this would be a good area for further study.

\subsection{Children's Claims Made with Parents}

Both accompanied and unaccompanied non-citizen young people run the risk of being rendered voiceless and invisible in the asylum process. For an accompanied child who appears as a derivative on her parent's asylum application, any independent claim to asylum by the child is 'typically subsumed under that of the parent and is not considered separately' ${ }^{68}$ Neither the Asylum Officer nor the Immigration Judge contemplates the derivative child's own claim independently from that of her parent's claim, even if her claim for asylum is much stronger than that of her parent. Should her parent's asylum application be successful, she will be allowed to remain in the United States. But should her parent's asylum application fail, the child will also be ordered removed from the United States.

66 INA, s. 316; 8 USC s. 1416. Children under 18 may not apply for naturalization.

67 INA, s. 242; 8 USC s. 1252. BIA appeals must be filed within 30 days of the final removal hearing. With the filing of the appeal, the child is granted a stay of removal. If further judicial review is sought, the child must seek a 'stay' of removal while the federal judicial review is pending.

68 B.A. Carr, 'Incorporating a "Best Interest of the Child" Approach into Immigration Law and Procedure' (2009) 12 Yale Human Rights and Development Law Journal 120, at 130. See also Women's Commission for Refugee Women and Children, Prison Guard or Parent?: INS Treatment of Unaccompanied Refugee Children (2002), p. 5, available at www.womenscommission.org/pdf/ins_det.pdf>; see also Salameda v. INS, 70 F.3d 447, 451 (7th Cir. 1995) ('In order to economize on its limited resources, the INS usually does not bother to institute a formal deportation proceeding against an alien who is likely to depart anyway, such as the minor child of parents who are being deported.'). 


\section{SPECIAL IMMIGRANT JUVENILE STATUS: A REMEDY FRUSTRATED BY PROCESS AND LACK OF ACCESS TO COUNSEL}

The United States has traditionally delegated all family law and child custody decisions to State authorities. Accordingly, immigrant children straddle a difficult legal line, trapped in the federal authority to make decisions about their deportation and needing the State's power to make decisions for their care and custody. As is explored in David Thronson's discussion of protections for immigrant youth, ${ }^{69}$ the US statutes create a bifurcated process that authorizes a child to secure lawful resident status as a special immigrant juvenile provided a State court with power to make care and custody determinations has made specific required findings. In reality, almost all migrant children will need to have a legal guardian or a clear determination of parental custody for permanency planning and integration purposes. As many of the children are living in households with undocumented parents or with families divided across borders, the State court guardianship or custody proceedings may be essential for that child to efficiently and appropriately access insurance benefits, school registration, and related other protections necessary for their long-term health and stability.

Unlike the immigration proceeding, where the federal government initiated the proceeding and the young person is automatically placed into an administrative court proceeding, the child has no direct way to access the family court in the US State where he or she resides. In most States, an adult or a State or local agency must initiate a proceeding and the child is the 'subject' of the proceeding. For example, a parent might bring an action to gain custody over a child and would name the child's other parent as a respondent. ${ }^{70}$

Children in federal detention have almost no ability to access the family court unless an advocate locates them within the detention center and can find a guardian or parent who is willing to seek a custodial determination. In these cases, the family court can only act if DHS consents to the family court proceeding. The conditions of release instruct the parent or other responsible adult to seek a family court guardianship in the appropriate State court. Sponsors are not instructed how to find assistance nor directed to the process in the family court for formal appointment. ${ }^{71}$

69) See David Thronson, Chapter 13. The statute is INA, s. 101(a)(27)(J); 8 USC s. 1101(a)(27)(J).

70) Custody determinations do meet the immigration law requirement that the child is 'dependent on the family court'.

${ }_{71}$ State procedures vary widely. In some States there is no 'guardianship' 
In a few States, it is possible for the child to self-petition and to initiate a proceeding in the family court that will satisfy the requirements of the special immigrant juvenile status findings specified in the federal immigration law. ${ }^{72}$ One example is found in Texas, where children have been able to petition to have a guardian or custodian named and the court appoints family law counsel to assist the child in meeting the requirements of service and the development of the factual record..$^{73}$

While some States appoint counsel for children, that appointment is not made until a petition is pending before the court. The obstacles to filing create a significant process barrier. If a child must seek the family court jurisdiction and he or she has no attorney who can help them navigate the web of laws, procedures and rules, the child is unlikely to successfully complete the family court proceeding. If they cannot navigate the State system, they are vulnerable but they also may have lost the opportunity to secure the special immigrant juvenile status defined in the immigration laws.

In 2016, even success in the family court and a filing of a petition for special immigrant juvenile status did not necessarily end the removal proceedings. Congress has limited this special protective visa to a total of 10,000 immigrants annually and no country may exceed more than 7 percent of that total. ${ }^{74}$ Accordingly, due to the high volume of applications, there are now multi-ycar waits for children from Central America, Mexico or India. DHS rarely agrees to a termination of the proceedings when the young person is waiting in this backlog. While the government

process but instead adults must seek custody as a parent or a third party grant of custody. See, e.g., North Carolina statutes that do not use a 'guardianship' concept but define only third party custody, available at www.ncga.state.nc.us/ EnactedLegislation/Statutes/HTML/BySection/Chapter_50/GS_50-13.2.html. The lack of clear guidance and direction for the parents and sponsors is a significant gap in helping the children secure permanency and integration. Worse still, in some family courts where natural parents have petitioned for custody and special immigrant juvenile findings, the family court clerk's office rejects the filings of the petitioning parent or guardian on the ground that the child doesn't need an order of custody or guardianship. For a report describing a survey of attorneys and the problems with access, see www.fordham.edu/download/downloads/id/3019/ findings_from_a_survey_of_lawyers_representing_immigrant_youth_eligible_ for_special_immigrant_juvenile_status_in_nys_family_court.pdf.

72 INA, s. 101(a)(27)(J); 8 USC s. 1101(a)(27)(J).

73 Texas FAM, s. 102.003, 'Standing to File Suit', available at http://codes. findlaw.com/tx/family-code/fam-sect-102-003.html.

74 See INA, s. 203(b)(4); 8 USC s. 1203(b)(4). The waiting periods are published monthly by the US Department of State in its Visa Bulletin, available at https://travel.state.gov/content/visas/en/law-and-policy/bulletin.html. 
may not vigorously seek deportation, the proceedings are only temporarily suspended.

\section{ACCESS TO LEGAL INFORMATION AND REPRESENTATION}

\subsection{Know Your Rights and Legal Orientation Programs}

The existing regulations and court procedures instruct Immigration Judges to advise every child that he or she has the right to have counsel, but the government will not pay for the representation. The judges provide the youth with a copy of the local list of low cost or free providers. ${ }^{75}$

In the past 10 years, a small office, the Office of Legal Access Programs (OLAP), within the EOIR has tried to improve efficiency and to help to identify victims of trafficking by offering 'legal orientation programs'. ${ }^{76}$ This Office has funded nonprofit organizations to enter into juvenile detention facilities and to staff a hotline for children's sponsors upon release. The programs are not funded to provide direct legal representation. In 2014, OLAP established a few representation programs and funded legal assistance for a small number of children. ${ }^{77}$

75 The list of free providers is available on the EOIR website. Many of the listed organizations will not accept cases of people in detention and are oversubscribed so that it is very possible that none of the organizations will accept representation of a child who called. See www.justice.gov/eoir/new-york-cityimmigration-court for a list of providers and more information.

76 US Department of Justice, Executive Office for Immigration Review, Office of Legal Access Programs (17 May 2017), available at www.justice.gov/ eoir/office-of-legal-access-programs. In the spring of 2018, the Department of Justice announced the suspension of the legal orientation program, and then two weeks later reversed its course and opted to temporarily continue the program. See J. Breisblatt, 'Justice Department Will Not Halt Legal Orientation Program for Detained Immigrants, Reversing Course for Now', American Immigration Council Immigration Impact, 25 April 2018.

77 See, e.g., US Department of Justice, Executive Office for Immigration Review, Baltimore Representation Initiative for Unaccompanied Children (BRIUC) (16 November 2016), available at www.justice.gov/eoir/baltimore-representation-initi ative-unaccompanied-children-briuc. Another novel program was the 2015 creation of the Justice AmeriCorps. The government appropriated approximately US\$1 million annually to provide seed grants to qualified hosting nonprofit organizations who hired 'fellows' to represent unaccompanied children younger than age 16. The goal of these pilot projects was to measure the ability of the programs to increase efficiency in the courts and to study the impact of representation for a particularly vulnerable population. The Trump Administration has proposed defunding all AmeriCorps 


\subsection{Right to Counsel}

While children in State court juvenile proceedings are entitled to the appointment of free legal representation, to date, no court has ordered that a child is entitled to free counsel in removal proceedings. ${ }^{78}$ The US constitutional guarantee of 'due process' of law is not, by its language, limited to citizens. ${ }^{79}$ In July 2014, a coalition of civil rights and nonprofit organizations filed suit on behalf of a proposed class action of unaccompanied juveniles and asserted that the federal government was denying the children a fair hearing because no free attorney was appointed to represent the children. ${ }^{80}$ The legal argument built upon the US constitutional law that provides counsel to indigent defendants in criminal cases and has provided counsel to indigent civil respondents where life or liberty was threatened. As of this writing, the class action litigation is stalled, as an appellate court ruled the issue could only be presented after a child had presented the issue in a removal hearing and preserved the issue in agency appeals and through statutory review, as required in the controlling statutes. ${ }^{81}$

A significant number of children appear in Immigration Court without any counsel. While most Immigration Judges will grant a continuance so that the child can try to find representation, the court is not obligated to grant these continuances. ${ }^{82}$ As of January 2017, 42 percent of all pending

programs. There are no published reports about the program's overall effectiveness. The Vera Institute is expected to release a report, see www.vera.org/projects/eval uation-of-justice-americorps-legal-services-for-unaccompanied-children-program/ learn-more.

78 In re Gault, 387 US 1 (1967) (requiring appointed counsel before the State can restrict a juvenile's liberty).

79 US Constitution, Amendment V.

80 JEFM v. Holder, No. 2:14-cv-01026-TSZ, 2015 WL 9839679 (WD Wash. 13 April 2015). The trial court initially refused to certify the full class but eventually certified a group of children seeking asylum protection. Some of the parties changed and the case was renamed $F L B$ v. Lynch, 2016 US Dist. LEXIS 82653 (WD Wash. 24 June 2016, No. C14-1026 TSZ).

81 See JEFM v. Lynch, 837 F.3d 1026 (9th Cir. 2016). While the court found the children likely did have a constitutional claim, it found that Congress had curtailed direct class action challenges in the statute. See INA, s. 242; 8 USC s. 1252. The parties filed a petition for rehearing in December 2016.

82 It is important to note that in April 2018, the Department of Justice imposed case completion quotas on Immigration Judges tied to their annual performance reviews. This raises concerns that Immigration Judges potentially will refuse continuances in an effort to push through cases to meet these metrics. See N. Miroff, 'Trump administration, seeking to speed deportations, to impose quotas on immigration judges', Washington Post, 2 April 2018. 
juvenile cases, over 31,000 children, lack representation. ${ }^{83}$ The released data appear to indicate that unrepresented children are able to secure relief only 4 percent of the time. ${ }^{84}$ To date no legislative remedy has been able to secure sufficient support for adoption. ${ }^{85}$

\subsection{Competence of Counsel}

One of the continuing challenges within the US system is that the skills and substantive knowledge required to adequately represent children cut across different specialties. Children in immigration removal proceedings need counsel well versed and familiar with the procedures and substantive protections inherent in that system of law. ${ }^{86}$ However, equally important is the need for counsel familiar with the State law governing the protection of children and the rules governing the State's power to make permanency and custody arrangements. At the current time in the United States, many States provide children with free appointed counsel but only in proceedings where the State began a proceeding that might remove the child from the care and custody of his or her natural family. Moreover, many of the experienced family law counsel within these systems have tended to ignore the immigration status of the children in family court proceedings. In a sense, this has been a benevolent ignorance, as citizenship is rarely a determinative factor in custody cases.

83 See TRAC, above n. 5.

84 See above n. 2.

85 Vulnerable Immigrant Voice Act, HR 1700, introduced in 2015-2016 Congress, available at www.congress.gov/bill/114th-congress/house-bill/1700. This Bill has not been reintroduced in the 2017 Congressional session.

${ }_{86}$ In 2010, the Supreme Court found that the failure to adequately advise a non-citizen of the direct immigration consequences of a conviction meant that the defense counsel had performed inadequately and that failure could be a basis for vacating the underlying conviction. Padilla v. Kentucky, 559 US 356 (2010). The opinion points out that the entire criminal justice system, not just defense counsel, has an obligation to make sure that the defendant is adequately informed. Accordingly, many criminal law prosecutors and judges are now building a more detailed factual record to demonstrate that the non-citizen is informed about the immigration consequences before any plea agreement. This concept needs to be extended to family and juvenile courts to ensure adequate protection of migrant children's rights. Ignoring a child's citizenship status could be missing an opportunity to assist the child in securing protective status. 


\section{CONCLUSION: PROCESS CAN SHAPE OUTCOMES}

It is difficult to separate the process protections from the statutory substantive protections for youth. Certainly, US law offers a number of varied protections for youth who entered the United States with or without visa documentation. However robust these protections, the complexity of the procedures, and the multitude of agencies a child must navigate in order to benefit from these protections, can be insurmountable. This suggests that the process alone may be one of the single worst barriers to child protection. $^{87}$

If children inside the United States and those apprehended at the border were given appointed counsel to provide them with both orientation and robust representation, the US would be able to protect and integrate many migrant children. Unfortunately, the US is using a removal hearing process without adequate representation and resources, making the promise of protection illusory.

87 See generally C. Thomas and L. Benson, 'Caught in the Web: Immigrant Children in Removal Proceedings', paper presented at NYLS Impact Seminar on Access to Justice, July 2016, available at http://digitalcommons.nyls.edu/cgi/ viewcontent.cgi?article $=1015 \&$ context $=$ impact_center. 